\begin{tabular}{|c} 
Ambiente \& Água - An Interdisciplinary Journal of Applied Science \\
ISSN 1980-993X - doi:10.4136/1980-993X \\
www.ambi-agua.net \\
E-mail: ambi.agua@gmail.com
\end{tabular}

\title{
Histopathological and hematological biomarkers in tambaqui Colossoma macropomum (Cuvier, 1816) from an environmental protection area of Maranhão, Brazil
}

\author{
ARTICLES doi:10.4136/ambi-agua.2266
}

Received: 04 Apr. 2018; Accepted: 23 Oct. 2018

\author{
Jonatas da Silva Castro ${ }^{1 *(D)}$; Camilla Fernanda Lima Sodré ${ }^{(D)}$; \\ Caroline Bogéa Souza ${ }^{2}$; ; Débora Batista Pinheiro Sousa ${ }^{3}$; \\ Raimunda Nonata Fortes Carvalho Neta ${ }^{2}$ iD

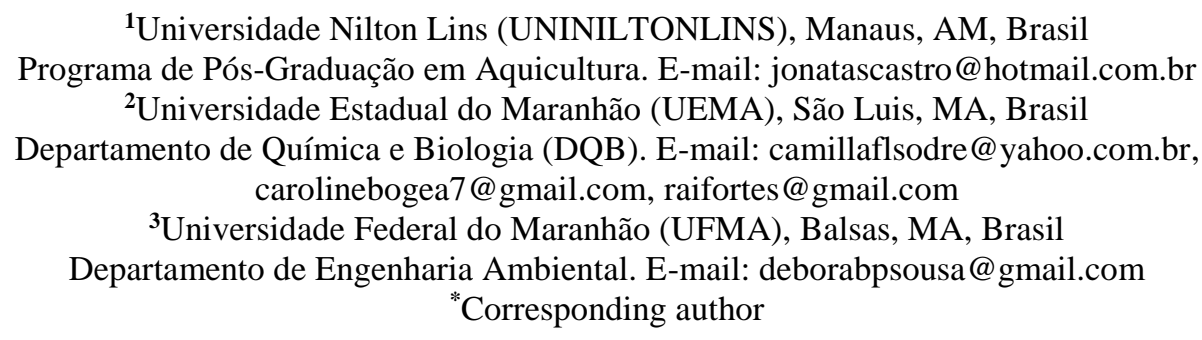

\section{ABSTRACT}

This study analyzed histopathological (gill lesions) and hematological (erythrocyte abnormalities) changes in tambaqui (Colossoma macropomum) in order to evaluate the water quality of fish farms in the Environmental Protection Area (EPA) of Maracanã, Maranhão, Brazil. Specimens of tambaqui were captured in two areas of EPA: A1) Serena Lagoon, and A2) River Ambude, in two seasonal periods, rainy and dry. For the hematological analyses, slides were made from the blood smear collected from the branchial arch of the fish. In the laboratory, the gills of each specimen were fixed in 10\% formalin and maintained in $70 \%$ alcohol until the usual histological technique. The branchial changes were more frequent during the dry season in both areas. In the fish collection in A2, the following changes were noted: mucosal cells $(78 \%)$, lamellar fusion $(90 \%)$, lamellar disorganization (100\%), lamellar narrowing (100\%), and epithelial displacement (96\%). In the fish collection in A1, the main lesions were: aneurysm (88\%), dilation of the capillaries (82\%), rupture of the capillaries (60\%). In addition, nuclear alterations, such as binucleate cells (BC), cells with an evaginated nucleus (CEN) and cells with a lobulated carved nucleus (CLCN), were observed in the fish from both areas. The frequency of abnormalities was higher in the fish from A2 (74\%) when compared to the fish from A1 (26\%). In conclusion, we found that these alterations proved to be sensitive biomarkers capable of differentiating water quality and fish health status in the two systems in the Maracanã EPA.

Keywords: aquatic monitoring, gill lesions, water quality. 


\section{Biomarcadores histopatológicos e hematológicos em tambaqui Colossoma macropomum (Cuvier, 1816) de uma área de proteção ambiental do Maranhão, Brasil}

\section{RESUMO}

Objetivou-se neste estudo analisar as alterações histopatológicas (lesões branquiais) e hematológicas (anormalidades eritrocíticas) em tambaqui (Colossoma macropomum), para avaliação da qualidade de água de pisciculturas da Área de Proteção Ambiental (APA) do Maracanã, Maranhão, Brasil. Exemplares de tambaqui foram capturados em duas áreas da APA: A1) Lagoa Serena; A2) Rio Ambude, em dois períodos sazonais (chuvoso e seco). Para as análises hematológicas foram confeccionadas lâminas a partir do esfregaço de sangue coletado no arco branquial dos peixes. No laboratório as brânquias de cada espécime foram fixadas em formol a $10 \%$ e mantido em álcool a $70 \%$ até a execução da técnica histológica usual. As alterações braquiais foram mais frequentes no período de estiagem nas duas áreas analisadas. Em peixes coletados em A2, as seguintes alterações foram observadas: células mucosas (78\%), fusão lamelar (90\%), desorganização lamelar (100\%), estreitamento lamelar (100\%), deslocamento do epitélio (96\%). Em peixes coletados em A1, as principais lesões foram: aneurisma (88\%), dilatação dos capilares (82\%), rompimento dos capilares (60\%). Além disso, nos peixes de ambas as áreas foram observadas alterações nucleares, como células binucleadas (BC), células com núcleo evaginado (CEN) e células com núcleo entalhado lobulado (CLCN). A frequência de anormalidades foi maior nos peixes de A2 (74\%) quando comparada com os exemplares de A1 (26\%). Em conclusão, consideramos que essas alterações se mostraram biomarcadores sensíveis capazes de diferenciar a qualidade de água e o estado de sanidade dos peixes em dois sistemas aquáticos na APA do Maracanã.

Palavras-chave: lesões branquiais, monitoramento aquático, qualidade de água.

\section{INTRODUCTION}

The monitoring aquatic environments is an important and necessary process in the management of natural resources, since it offers the opportunity to diagnose the possible impacts caused by anthropic action. This process contributes with basic information to evaluate the presence of chemical contaminants and thus better comprehend their performance in the physiology of aquatic organisms. This knowledge is fundamental in order to generate policies relating to the management of aquatic systems (Brito et al., 2012).

Fish are used in aquaculture as a food source; however, because of their potential to accumulate pollutants present in the water column, and because of biomagnification by the trophic chain, they represent an important route of contamination for human populations (Oliveira Ribeiro et al., 2006). The different kinds of pollutants present in water and sediments can cause diverse modifications in different biological levels (cellular, tissue and systemic). Thus, these changes are considered as good indicators of the damage that both, organic and inorganic contaminants can cause in fish (Sousa et al., 2013).

Several methodologies have been applied in the assessment of the conditions of aquatic environments, such as biomarkers in fish. These analyses allow the identification of initial biological changes caused by the organisms' exposure to contaminants and may be useful to support monitoring and environmental management actions (Amaral et al., 2006). Among the advantages of applying this methodology, Sousa et al. (2013) highlight the speed, the low cost and the easy interpretation of results.

Tambaqui (Colossoma macropomum) is one of the species grown in Maracanã the EPA, 
standing out for its high economic and ecological value, because the species is cultivated in tanks and captured frequently in the rivers of the region. In addition, this species is considered a bioindicator due to the ease of handling and maintenance in the laboratory and has been used to evaluate the quality of aquatic environments (Fortes Carvalho Neta et al., 2015). A study carried out by Castro et al. (2014) revealed that the use of biomarkers in fish is efficient in support of public bodies' decisions, in order to carry out monitoring actions in these environments.

The EPA of Maracanã is located near the industrial district of a large city, São LuísMaranhão/Brazil, and suffers from pollution from the nearby industrial facilities. In addition, despite the requirement of the law that created the protected area, there is still no environmental management plan. In this sense, studies using biomarkers in fish from different aquatic environments, especially with rivers and with cultivation systems practiced in the region, can provide subsidies for biomonitoring that must be performed and can integrate the environmental management plan.

The objective of this study was to analyze the morphological (gill lesion) and hematological (erythrocyte abnormalities) biomarkers to evaluate the water quality of fish farms and the health condition of tambaqui of the Environmental Protection Area of Maracanã, São Luís, MA, Brazil.

\section{MATERIAL AND METHODS}

\subsection{Sample collection}

The capture of tambaqui was approved by the Ethics Committee of the State University of Maranhão (protocol number 21/2013) and complied with the guidelines of the Brazilian College of Animal Experimentation (COBEA; http://www.cobea.org.br). Forty specimens were collected at two collection points with gill nets: A1 = Serena Lagoon $(n=20)$; $A 2=$ Ambude River ( $n=20$ ), during the dry season of 2012 (October/November) and rainy season (April/May) of 2013.The first capture point is characterized as a semi-intensive fish farming system, presenting poor management of the animals, geographical coordinates $2^{\circ} 38^{\prime} 2.99^{\prime \prime} \mathrm{S} \mathrm{/}$ $44^{\circ} 17^{\prime} 55.58^{\prime \prime} \mathrm{W}$. The second capture site is characterized as being the source of the Ambude River, highly impacted by anthropic action, geographic coordinates $2^{\circ} 37^{\prime} 45.01^{\prime \prime} \mathrm{S} /$ $44^{\circ} 17^{\prime} 44.87^{\prime \prime} \mathrm{W}$ from the EPA of Maracanã (Figure 1). The animals were placed into plastic bags and kept in iceboxes to be transported to the Laboratory of Biomarkers in Aquatic Organisms (LabBOAq) of the State University of Maranhão, where biometric data regarding Total Length (TL), Standard Length (SL) in $\mathrm{cm}$ and Total Weight (WT) in g was determined. The sexual determination of the fish was according to the macroscopic evaluation of the gonads (Vazzoler, 1981).

\subsection{Physico-chemical parameters and water analyses}

Simultaneously to the fish catch, the physico-chemical parameters of the water such aspH, temperature, dissolved oxygen, turbidity and levels of ammonia, and nitrites were measured using a multiparameter probe (SX751 - SANXIN). Water samples were collected in triplicate from the Serena Lagoon (A1) and the Ambude River (A2) in order to determine the contaminant levels. The samples were analyzed for metals such as copper $(\mathrm{Cu})$, iron $(\mathrm{Fe})$, lead $(\mathrm{Pb})$, manganese $(\mathrm{Mn})$ and zinc $(\mathrm{Zn})$. The concentrations of metals in the water were determined in the Soil Laboratory of the UEMA, using Inductively Coupled Plasma Emission Spectrometry (ICP-Varian 720-ES). For the validation of the employed method, Standard Reference Material, 1640 Trace Elements in Water, U.S Department of Commerce, National Institute of Standards and Technology, Gaithersburg MD 20899 was used.The results were reported in milligrams 
$(\mathrm{mg} / \mathrm{L})$. Blanks and certified reference materials were used to ensure the quality of analyses. The measurements were performed in triplicate.

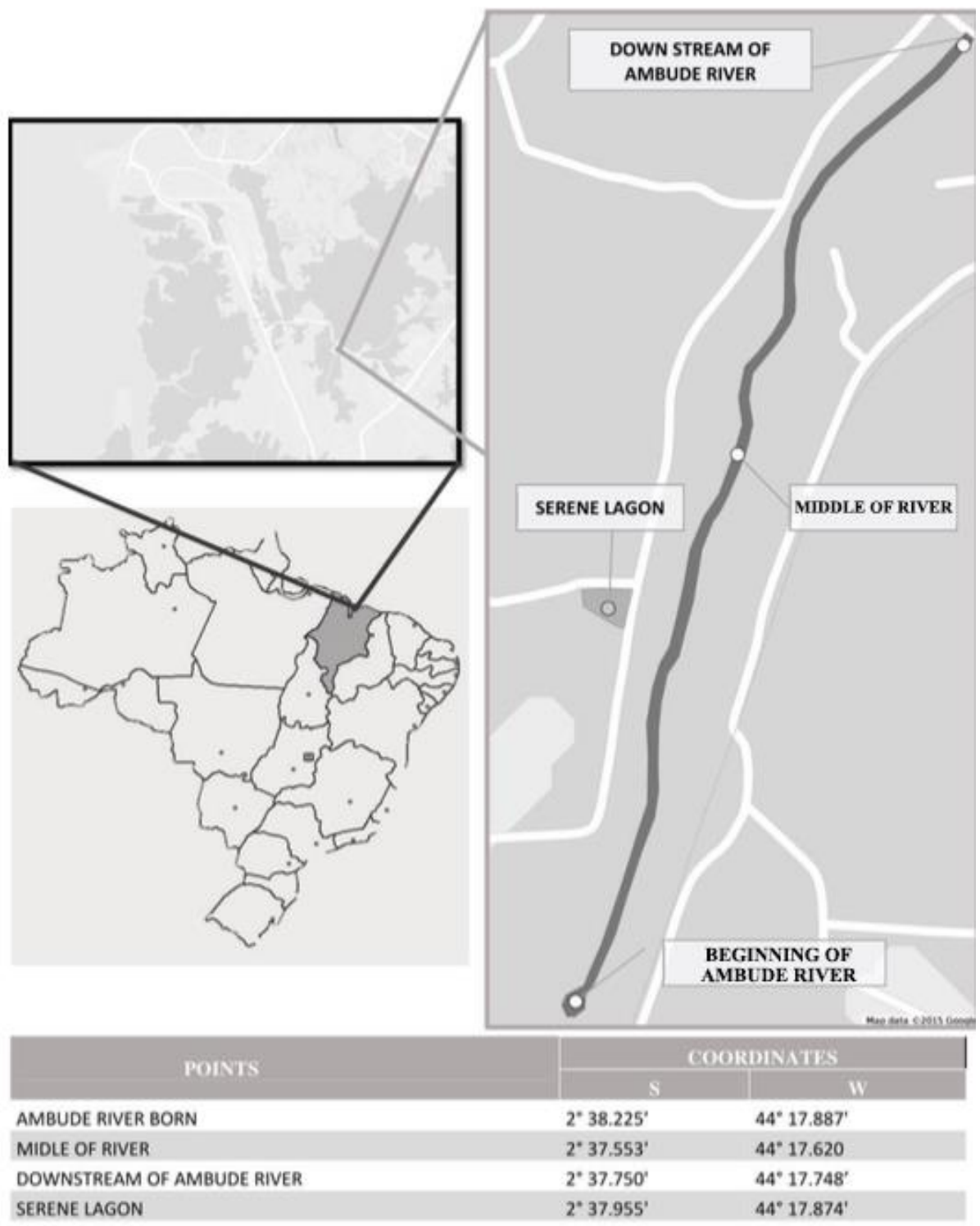

Figure 1. Capture region of specimens C. macropomum at EPA of Maracanã. Sites: Ambude River and Serena Lagoon.

\subsection{Hematological analyses}

Blood collection via the gill area was performed in the field. The fish were put in a vat of water and anesthetized with eugenol $(10 \mathrm{mg} / \mathrm{L})$, followed by blood collection using a heparinized syringe. The fish were then placed in plastic bags, put in boxes with ice and transported to the Laboratory of Biomarkers in Aquatic Organisms of the State University of Maranhão.

Genotoxic analyses were carried out from a blood smear obtained from a part of the blood of the branchial vessels. One drop of blood from each fish was dripped onto a microscopic slide in order to perform the smear. Subsequently, the slides were fixed in absolute ethanol during 30 minutes. After drying, the slides were stained in $10 \%$ Giemsa diluted in phosphate buffer, pH 6.8. Twenty slides were prepared from each fish and 2000 cells were analyzed for each slide, respectively. 


\subsection{Histopathological analyses}

The first branchial arch of each fish was removed and fixed in $10 \%$ formaldehyde. The gill samples were then dehydrated in increasing series of alcohol, deparaffinized in xylene, and included in paraffin. Cross sections of approximately $5 \mu \mathrm{m}$ thick were cut using a microtome (Leica RM2265). All observations of branchial lesions were made with a Zeiss light microscope (Carl Zeiss AG, Germany), equipped for the acquisition of images taken with the AxioCam camera (Zeiss, Jena, Germany). The histopathological changes were observed and photomicrographed. They were ordered according to the severity degree of the lesions, according to the scale - I (small injury), II (moderate injury), and III (severe injury), as suggested by Bernet et al. (1999).

\subsection{Data analyses}

The data were expressed by mean and standard deviation from the mean. The data were tested for their normality using the Shapiro-Wilk test. Subsequently, the number of gill and cell changes with micronucleus and morphological abnormalities between the areas were compared using the Student's t-test $(\mathrm{p}<0.05)$. The statistical analyses described were performed using the R Software (R Development Core Team 2016).

\section{RESULTS AND DISCUSSION}

The results of the physicochemical analyses of water are listed in Table 1 . The results of ammonia, temperature, $\mathrm{pH}$, dissolved oxygen, turbidity, and nitrite in each capture area are in accordance with the values recommended by CONAMA - Resolution $N^{\circ} 430 / 2011$. The metal concentrations $(\mathrm{Cu}, \mathrm{Fe}, \mathrm{Pb}, \mathrm{Mg}$ ) (Table 1) showed values higher than the acceptable limits (Class 2 waters - which can be used for aquaculture and fishing) defined by the Brazilian standard for some metals (CONAMA 357/2005 and 430/2011) in the A2 site.

Table 1. Abiotic data and transition metals values collected at the two capture sites of tambaqui at EPA of Maracanã, São Luís-MA.

\begin{tabular}{lccccc}
\hline Parameters & \multicolumn{3}{c}{ Dry season } & \multicolumn{3}{c}{ Rainy season } \\
\hline & A1 & A2 & A1 & A2 & ${ }^{a}$ Recommended values \\
\hline Ammonia $(m g ~ L)$ & 0.5 & 0.25 & 0.4 & 0.21 & $\leq 3.7 \mathrm{mg} / \mathrm{L}^{\mathrm{b}}$ \\
Turbidity $(\mathrm{mg} \mathrm{L})$ & 23.5 & 17 & 22 & 18 & $<100 \mathrm{UNT}$ \\
Dissolved $\mathrm{O}_{2}\left(\mathrm{mg} \mathrm{L}^{-1}\right)$ & 11 & 9 & 11.4 & 8.8 & $>5 \mathrm{mg} / \mathrm{L}^{\mathrm{b}}$ \\
$\mathrm{pH}$ & 7.5 & 7,3 & 7.3 & 7 & $6.5-8.0^{\mathrm{b}}$ \\
Temperature $\left({ }^{\circ} \mathrm{C}\right)$ & 30 & 29.8 & 29.6 & 29.2 & $28-32^{\circ} \mathrm{C}^{\mathrm{b}}$ \\
Copper $\left(\mathrm{mg} \mathrm{L}^{-1}\right)$ & $\mathrm{ND}$ & 0.0160 & $\mathrm{ND}$ & 0.0159 & $\leq 0.009^{\mathrm{b}}$ \\
Iron $\left(\mathrm{mg} \mathrm{L}^{-1}\right)$ & $\mathrm{ND}$ & 2.59 & $\mathrm{ND}$ & 2.55 & $\leq 0.3^{\mathrm{b}}$ \\
Lead $\left(\mathrm{mg} \mathrm{L}^{-1}\right)$ & $\mathrm{ND}$ & 0.0317 & $\mathrm{ND}$ & 0.0314 & $\leq 0.01^{\mathrm{b}}$ \\
Manganese $\left(\mathrm{mg} \mathrm{L}^{-1}\right)$ & $\mathrm{ND}$ & 0.210 & $\mathrm{ND}$ & 0.320 & $\leq 0.1^{\mathrm{b}}$ \\
Zinc $\left(\mathrm{mg} \mathrm{L}^{-1}\right)$ & $\mathrm{ND}$ & 0.195 & $\mathrm{ND}$ & 0.210 & $\leq 0.18^{\mathrm{b}}$ \\
\hline
\end{tabular}

$\mathrm{mg}=$ milligrams; $\mathrm{L}=$ liters; ${ }^{\mathrm{b}}$ Recommended values are based on Resolution Number 357 of the Brazilian National Environmental Council (CONAMA, 2005; 2011); $\mathrm{ND}=$ not detected.

In the present study, higher values of ammonia, $\mathrm{pH}$, and turbidity were observed in the Serena Lagoon, probably due to the lack of water circulation and the excessive use of animal food in the environment, since this is a fish pond. According to Mercante et al. (2008), the increase in $\mathrm{pH}$ in the environment is associated with the increase of ammonia. In cultivation ponds, the main sources of incorporated nitrogen compounds occur through feed, animal food, 
and fertilizers used in the nurseries which contain nitrogen, mainly in the form of ammonia and nitrate. The excess of these elements in the cultivation environment can delay the fish growth, besides being nutrients consumed by phytoplankton, causing the excessive growth of these algae, leading to eutrophication of the environment, hindering the penetration of light (Mercante et al., 2008).

The Ambude River showed the presence of all measured metals, with high values of $\mathrm{Cu}$, $\mathrm{Pb}$, and $\mathrm{Fe}$. These findings can be related to the anthropic activities carried out at this site caused by liquid residues and pollution originated from the absence of basic sanitation. The presence of housing and communities along the aquatic bodies, as well as the use of pesticide chemicals from agriculture, domestic and industrial effluents that are considered to be major sources of metals for aquatic environments (Moiseenko and Kudryavtseva, 2001).

The statistical analyses of the results of the biometric data for male and female tambaqui from the two sites of EPA of Maracanã are expressed in Table 2. The fish collected in Serena Lagoon had higher values of total weight, total length and standard length in relation to the specimens collected in Ambude River.

Table 2. Biometric data of male and female fish collected at Serena Lagoon (A1) and Ambude River (A2), EPA of Maracanã, São Luís-MA.

\begin{tabular}{lcccc}
\hline \multicolumn{5}{c}{ Average \pm Standard deviation } \\
\hline Parameters & \multicolumn{2}{c}{ Serena Lagoon } & \multicolumn{2}{c}{ Ambude River } \\
\hline \multicolumn{4}{c}{ (Dry Season) } & \multicolumn{2}{c}{ (Rainy Season) } \\
\hline TL $(\mathrm{cm})$ & Females & Males & Females & Males \\
SL $(\mathrm{cm})$ & $27,5 \pm 2,36$ & $32,4 \pm 3,33$ & $23,4 \pm 4,8$ & $20,4 \pm 4,4$ \\
TW $(\mathrm{cm})$ & $646,5 \pm 112,33$ & $568,9 \pm 165,93$ & $330,4 \pm 51,40$ & $230,2 \pm 51,7$ \\
\hline
\end{tabular}

The biometric data of the analyzed specimens confirm that there is some alteration in the fish tanks and in the EPA of Maracanã's rivers. The data obtained for the fish in A2 presented lower values of total length (TL), standard length (SL) and total weight (TW) in relation to the specimens collected in the A1. These results entrench the influence of potentially contaminated environments on the zootechnical performance of these animals. The presence of transition metals such as iron, copper, zinc, and cobalt in aquatic environments are considered essential elements of biological processes; however, concentrations above the required level of these elements lead to organic dysfunctions including lack of appetite, reduced growth and stress (Gharedaashi et al., 2013).

Nuclear morphological changes (NC) and micronuclei were found in erythrocytes of $C$. macropomum at both sampling sites, but did not present seasonal differences between the areas $(\mathrm{p}>0,05)$. However, the highest values were found in the dry period. The main types of NC were: binucleate cell (BC), cell with an evaginated nucleus (CEN) and cell with a lobed grooved core (CLGC) (Figure 2). The abnormalities were more frequent in the Ambude River (74\%) than in the Serena Lagoon (26\%).

The hematological changes showed that fish from both areas suffer some kind of environmental impact related to substances probably derived from the leaching process of agrochemicals from the farming systems in the region or from industrial activities carried out in the vicinity of the EPA of Maracanã. According to Souza and Fontanelli (2006), the abnormalities found in fish erythrocytes may be related to cytotoxicity processes, influences on cell division and genotoxicity or mutagenicity. The morphological changes found in fish erythrocytes may appear as a consequence of the effect of chemical, toxic, genotoxic, mutagenic 
and carcinogenic contaminants to which fish are exposed in a contaminated environment (Palhares e Grisolia, 2002). According to Fenech (2000), these abnormalities are related to errors occurring during mitosis or meiosis, with cell death processes (necrosis and apoptosis), as well as genotoxicity and mutagenicity.

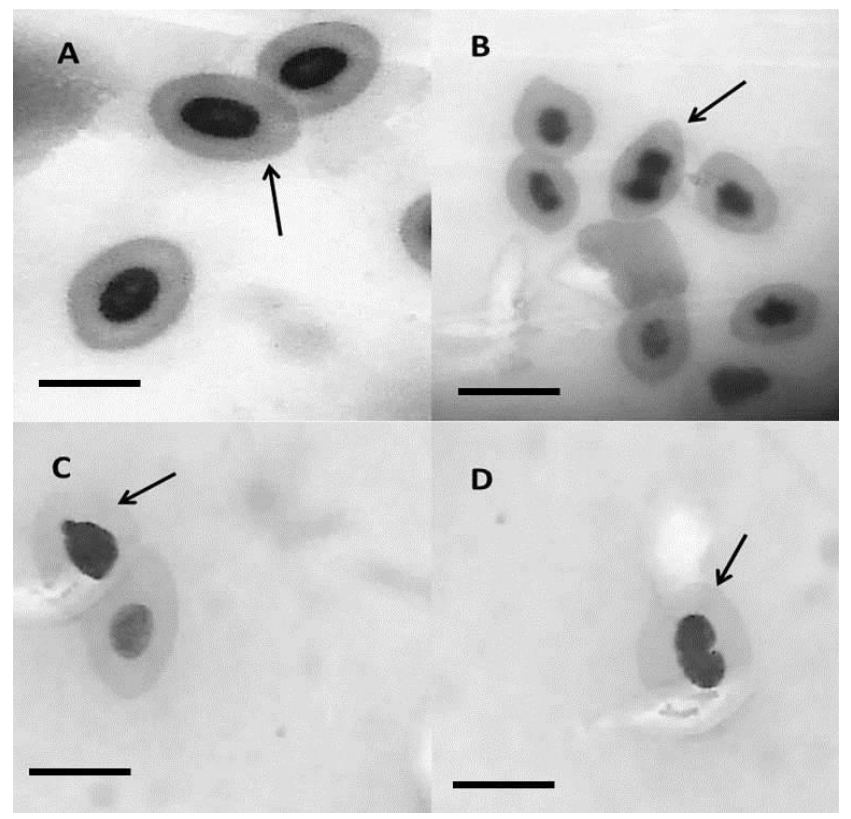

Figure 2. Photomicrography of C. macropomum erythrocytes collected at Serena Lagoon, APA of Maracanã. A) Erythrocytes showing normal cells (arrow); B) Erythrocytes showing a binucleated cell (arrow); C) Erythrocytes showing a cell with an evaginated nucleus (arrow); D) Erythrocytes showing a lobed grooved cell. Giemsa 100x.

The histopathological analyses performed on the fish gills collected from both regions of EPA of Maracanã showed the following morphological changes: mucosal cells, lamellar fusion, lamellar disorganization, lamellar narrowing, epithelial displacement, aneurysm, capillary dilatation and capillary rupture. The fish captured from the Ambude River had a higher percentage of branchial lesions in both seasons, rainy and dry (Figure 3).

In general, the analyses performed on the fish gills presented lesions of different severity levels (Bernet et al., 1999). The fish from the Ambude River presented the highest percentage of branchial alterations; this factor could be related to the leaching process of the pollutants, which are carried by the rain to the rivers. Castro et al. (2014) when analyzing the H. malabaricus species collected in the same region, identified lesions similar to those found in this study.The authors suggest the hypothesis that such lesions were caused by the release of rural and industrial effluents in the aquatic bodies of this region. Fortes Carvalho Neta et al. (2015) affirm that pollution in this region has intensified in recent years, both by the agropastoral systems and by the large industries installed around this Environmental Protection Area, causing serious problems in the aquatic environment, such as the decrease of dissolved oxygen, temperature oscillation, lack of nutrients and also the eutrophication of these environments. Our results are in agreement with the data found by Fortes Carvalho Neta et al. (2015) and Castro et al. (2014) and indicate that all these problems can cause stress to the fish and cause changes in their morphological structures, such as the severe branchial lesions found in the specimens analyzed in the Ambude River.

\section{IPABH}



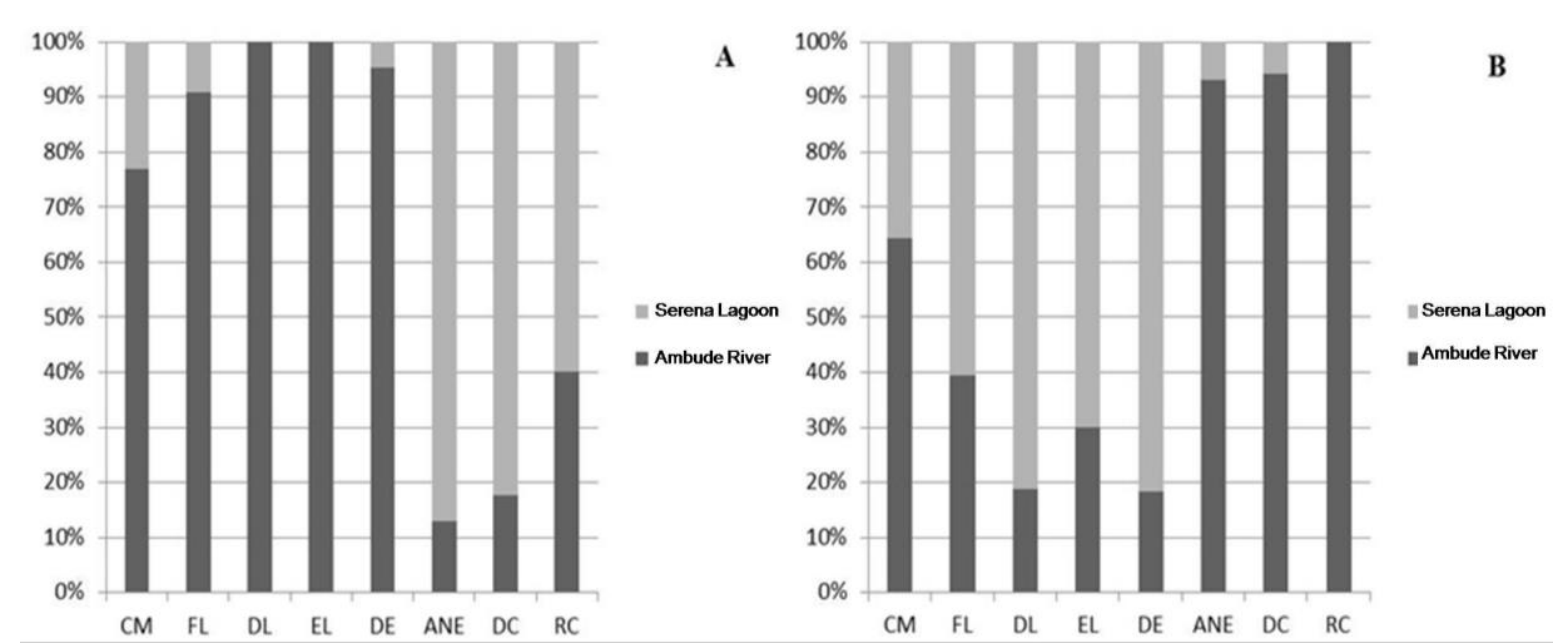

Figure 3. (A) Percentage of the branchial lesions found in the fish from the Ambude River and the Serena Lagoon in the dry season; (B) Percentage of the branchial lesions found in the fish from the Ambude River and the Serena Lagoon in the rainy season. CM (mucous cells); FL (lamellar melting); DL (lamellar clutter); EL (lamellar narrowing); DE (displacement of the epithelium); ANE (aneurysm); DC (dilation of capillaries); RC (capillary rupture).

Studies performed by Nogueira et al. (2008), using the species Pimelodus maculatus captured in the Furnas-MG reservoir (Brazil), identified the following lesions: aneurysm, cell proliferation in the secondary lamella and branchial filament, epithelial displacement in the branchial filament, hypertrophy, blood congestion in the marginal bloodstream and lamellar fusion; these injuries are related to the development of agricultural activities that are being carried out near the reservoir banks, contributing to an increase in the entrance of fertilizers and raw sewage in several areas. These data are similar to those obtained for the fish in the present study. Nevertheless, the biomarkers we used are effective in indicating the effect of pollutants, but they are not specific. This suggests that studies on other biomarkers and additional chemical analyzes on water and sediment should be undertaken in the region to support a biomonitoring program for the Environmental Protection Area.

\section{CONCLUSIONS}

The frequency of gill changes and nuclear alterations in tambaqui erythrocytes was higher in A2 than in A1, indicating that fish from the river are under more intense stress due to pollution from the industrial zone located near the EPA of Maracanã. However, the fish farming systems are also presenting responses that indicate stress, probably due to inappropriate management practices in the fish farms in the Environmental Protection Area. The biomarkers evaluated indicated that the health of fish from the EPA of Maracanã may be affected; in addition, the quality of the fish produced in the fish farming systems of the region needs to be monitored.

\section{ACKNOWLEDGEMENTS}

We would like to thank the Foundation for Scientific Research and Development of Maranhão (FAPEMA) for granting the scholarship to the first author, the Group of Research in Ecotoxicology and Monitoring of Aquatic Environments (GPEMAAq) of the State University of Maranhão, and the staff of the Laboratory of Biomarkers in Aquatic Organisms (LABOAq) for all the support. 


\section{REFERENCES}

AMARAL, A.; SOTO, M.; CUNHA, R.; MARIGÓMEZ, I. \& RODRIGUES, A. Bioavailability and cellular effects of metals on Lumbricus terrestris in habiting volcanic soils. Environmental Pollution, v. 142, p. 103-108, 2006. https://doi.org/10.1016/j.envpol.2005.09.011

BERNET, D.; SCHIMIDT, H.; MEIER, W.; BURKHRADT-HOLM, WHALI, T. Histopatology in fish: proposal for a protocol to assess aquatic pollution. Journal Fishery Diseases, n. 22, p. 25-34, 1999. https://doi.org/10.1046/j.1365-2761.1999.00134.x

BRITO, I. A.; FREIRE, C. A.; YAMAMOTO, F. Y.; ASSIS, H. C. S.; SOUZA-BASTOS, L. R.; CESTARI, M. M. et al. Monitoring water quality in reservoirs for human supply through multi-biomarker evaluation in tropical fish. Journal of Environmental Monitoring, v. 14, p. 615-625, 2012. http://dx.doi.org/10.1039/C2EM10461J

CASTRO, J. S.; SILVA, J. S.; FREITAS, L. C.; CARVALHO-NETA, R. N. F. Biomarcadores histopatológicos na espécie Hoplias malabaricus(Pisces, Osteichthyes, Erythrinidae) em uma Unidade de Conservação de São Luís (MA). Arquivo Brasileiro de Medicina Veterinária e Zootecnia, v. 66, n. 6, p. 1687-1694, 2014. https://doi.org/10.1590/16787414

CONSELHO NACIONAL DO MEIO AMBIENTE CONAMA. Resolução $n^{\circ} 357$. Diário Oficial [da] União: seção 1, Brasília, DF, p. 1-23, 17 mar. 2005.

CONSELHO NACIONAL DO MEIO AMBIENTE CONAMA. Resolução $n^{\circ}$ 430. Diário Oficial [da] União: seção 1, Brasília, DF, n. 92, p. 89, 16 maio 2011.FENECH, M. The in vitro micronucleus technique. Mutation Research, v. 455, p. 81- 95, 2000. https://doi.org/10.1016/S0027-5107(00)00065-8

FORTES CARVALHO-NETA, R. N.; PINHEIRO-SOUSA, D. B.; DE MACÊDO SOBRINHO, I. C.; HORTON, E. Y.; ALMEIDA, Z. S.; TCHAICKA, L. et al. Genotoxic and hematological parameters in Colossoma macropomum (Pisces, Serrasalmidae) as biomarkers for environmental impact assessment in a protected area in northeastern Brazil. Environmental Science Pollution Research, v. 22, n. 20, p. 15994-16003, 2015. https://doi.org/10.1007/s11356-015-4748-4

GHAREDAASHI, E.; NEKOUBIN, H.; IMANPOOR, M. R.; TAGHIZADEH, V. Effect of copper sulfate on the survival and growth performance of Caspian Sea kutum, Rutilus frisii kutum. SpringerPlus, v. 2, p. 1- 5, 2013. https://doi.org/10.1186/2193-1801-2-498

MERCANTE, C. T. J.; ESTEVES, K. E.; PEREIRA, J. S.; OSTI, J. S. Limnologia na aquicultura: estudo de caso em pesqueiros. São Paulo: Instituto de Pesca, 2008. 15 p.

MOISEENKO, T. I.; KUDRYAVTSEVA, L. P. Trace metal accumulation and fish pathologies in areas affected by mining and metallurgical enterprises in the Kola region, Russia. Environmental Pollution, v. 114, p. 285-297, 2001. https://doi.org/10.1016/S02697491(00)00197-4

NOGUEIRA, D. J.; CASTRO, S. C.; RIGOLIN-SÁ, O. Utilização das brânquias de Astyanax altiparanae (Garutti \& Britski, 2000) (Teleostei, Characidae) como biomarcador de poluição ambiental no reservatório UHE Furnas-MG. Revista Brasileira de Zoociências, v. 11, p. 227-232, 2008.

\section{IPABH}

Rev. Ambient. Água vol. 14 n. 1, e2266 - Taubaté 2019 
OLIVEIRA RIBEIRO, C. A.; FILIPAK NETO, F.; MELA, M.; SILVA, P. H.; RANDI, M. A. F.; RABITTO, I. S. et al. Hematological findings in neotropical sh Hoplias malabaricus exposed to subchronic and dietary doses of methylmercury, inorganic lead, and tributyltin chloride. Environmental Research, v. 101, n. 1, p. 74- 80, 2006. https://doi.org/10.1016/j.envres.2005.11.005

PALHARES, D.; GRISOLIA, C. K. Comparison between the micronucleus frequencies of Kidney and gill erythrocytes in tilapia fish, following mitomycin C treatment. Genetics and Molecular Biology, v. 25, n. 3, p. 281- 284, 2002. http://dx.doi.org/10.1590/S141547572002000300005

SOUZA, T. S.; FONTANELLI, C. S. Micronucleus test and observation of nuclear alterations in erythrocytes of Nile tilapia exposed to waters affected by refinery effluents. Mutation Research, v. 605, p. 87- 93, 2006. https://doi.org/10.1016/j.mrgentox.2006.02.010

SOUSA, D. B. P.; ALMEIDA, Z. S.; FORTES CARVALHO NETA, R. N. Biomarcadores histológicos em duas espécies de bagres estuarinos da Costa Maranhense, Brasil. Arquivo Brasileiro de Medicina Veterinária e Zootecnia, v. 65, p. 369-376, 2013

VAZZOLER, A. E. A. de M. Manual de métodos para estudos biológicos de populações de peixes: reprodução e crescimento. Brasília: CNPq-Programa Nacional de Zoologia, 1981. $108 \mathrm{p}$. 